\title{
PENGARUH KOMPETENSI DAN PELATIHAN TERHADAP KINERJA KARYAWAN PT ADARO ENERGY TBK
}

\author{
Ilman Ataunur ${ }^{1)}$ \\ Eny Ariyanto ${ }^{2)}$ \\ 1)Program Strata 2 Magister Manajemen, Universitas Mercu Buana Jakarta \\ e-mail:ataunur@yahoo.com \\ 2)Program Strata 2 Magister Manajemen, Universitas Mercu Buana Jakarta \\ e-mail: eny_ariyanto@yahoo.com
}

\begin{abstract}
To support the strategic objectives and facing the challenges of a constantly evolving organization, it needs employees with high performance. If the performance of employees increased the effectiveness and productivity of the company will increase as well. Competence and training are factors that lead to employee performance improvement. Competency can help organizations create a culture of high performance. While, the training that has been developed through phases planned and programmed process will have a direct impact on employee performance. This study aims to analyze how strong the influence of competence and training to employees performance of PT Adaro Energy Tbk, either partially or simultaneously. The research method used was survey with the design of associative research. Research hypothesis had been tested using multiple linear regression. From the research results proved the competence contributed significantly strong positive effect on performance. However, training gave weakly significant positive effect on performance. Simultaneously, competence and training had a dominant significant positive effect on employee performance, which is showed by a coefficient of determination of $73.6 \%$.
\end{abstract}

Keywords: competence, training, performance

\section{PENDAHULUAN}

Sumberdaya manusia adalah merupakan salah satu sumber daya organisasi yang memiliki peran penting dalam mencapai tujuannya. Setiap organisasi dikelola manusia. Tanpa manusia, organisasi itu tidak ada. Tantangan dan peluang dalam menciptakan dan mengelola organisasi kerap kali bersumber dari masalah-masalah yang ada kaitannya dengan manusia. Oleh karena itu mengelola sumberdaya manusia (SDM) adalah sumber daya paling vital merupakan aktivitas sentral dan strategis.

PT Adaro Energy Tbk sebagai kelompok perusahaan pertambangan dan energi yang berfokus pada bisnis pertambangan batubara yang terintegrasi melalui anak-anak perusahaannya mempunyai dua aset yang penting dalam menjalankan bisnisnya yaitu coal (batubara) dan people (sumber daya manusia). Aset batubara dinilai dari berapa banyak reserve (cadangan) yang dimiliki perusahaan. Sedangkan aset kedua adalah SDM, yang bertugas mengendalikan pemrosesan batubara seperti proses eksplorasi, eksploitasi, pemasaran batubara, proses keuangan dan proses lainnya. Pada akhirnya aset kedua (SDM) yang akan mengendalikan aset pertama, sehingga aset kedua inilah menjadi aset terpenting bagi perusahaan. Bila perusahaan ingin menjadi yang terbaik, hal ini sangat tergantung dari para karyawannya. 
Dengan memiliki sumber daya batubara sampai 12 miliar ton, Adaro merupakan salah satu dari segelintir produsen batubara di dunia yang dapat memberikan pasokan batubara yang handal dan dalam jangka waktu yang panjang kepada perusahaan-perusahaan listrik terkemuka yang sedang membangun pembangkit listrik berbahan bakar batubara di seluruh wilayah Asia. Perjanjian pasokan jangka panjang dengan perusahaan-perusahaan ini akan memungkinkan Adaro untuk mencapai target produksi jangka menengahnya yang telah ditetapkan sebesar 80 juta ton per tahun dari jumlah produksi sebesar 52,3 juta ton pada tahun 2013. Adaro menjalankan serangkaian bisnis yang terintegrasi secara vertikal, dengan beberapa anak perusahaan yang beroperasi dari pertambangan sampai energi atau dikenal dengan slogan from pit to power yang meliputi pertambangan, tongkang, pemuatan kapal, pengerukan, jasa pelabuhan, pemasaran dan ketenagalistrikan.

Untuk mendukung tujuan strategis perusahaan dan menjalankan tantangan yang terus berkembang diperlukan karyawan yang memiliki kinerja yang mampu mencapai target atau di atas target yang telah ditetapkan perusahaan pada masing-masing karyawan (job goals). Kinerja merupakan hasil pekerjaan yang mempunyai hubungan terhadap tujuan strategis organisasi Apabila hasil kinerja karyawan tidak dioptimalkan maka akan mempengaruhi kinerja organisasi yang tidak optimal sebaliknya jika kinerja karyawan yang meningkat, maka efektivitas dan produktivitas perusahaan pun akan meningkat pula.

Data penilaian kinerja karyawan merupakan ukuran yang dapat digunakan untuk menilai kinerja seseorang karena di dalamnya mencakup indikator-indikator untuk mengukur kinerja karyawan yaitu kualitas dan kuantitas serta perilaku karyawan dalam bekerja. Salah satu masalah yang dialami oleh Adaro adalah terjadinya pencapaian kinerja karyawan yang belum optimal. Indikator belum optimalnya kinerja karyawan pada tiga tahun kebelakang yaitu persentase karyawan yang mempunyai pencapaian kinerja sesuai target dan di atas target cenderung menurun. Pada tahun 2013 hanya 15\% karyawan mempunyai pencapaian kinerja sesuai target, bahkan sejak tahun 2012 sampai 2013 tidak ada karyawan yang mempunyai pencapaian kinerja di atas target yang telah ditetapkan.

Pencapaian kinerja karyawan yang belum optimal tersebut bisa dikarenakan target pencapaian kinerja yang telah ditetapkan perusahaan kepada karyawannya setiap tahun semakin tinggi, mengingat tantangan perusahaan kedepan semakin berat. Oleh sebab itu karyawan harus menjawab tantangan tersebut dengan memberikan kinerja terbaik agar target kerja yang diembannya dapat tercapai dengan optimal dan dapat mendukung keberlanjutan perusahaan.

Banyak faktor yang menyebabkan sumber daya manusia memiliki kinerja unggul, sehingga mampu mendorong keberhasilan organisasi, salah satunya adalah kompetensi. Organisasi akan berkembang dan mampu bertahan apabila didukung oleh karyawan-karyawan yang kompeten di bidangnya. Adaro sudah mempunyai kriteria kompetensi tertentu yang diharapkan dari para karyawannya. Metode untuk mengukur atau mengevaluasi kompetensi individu adalah dengan kompetensi assessment. Masalah dalam kompetensi yang terjadi di Adaro adalah masih tingginya hasil assessment karyawan yang belum memenuhi kriteria sesuai dengan kompetensi yang dipersyaratkan yaitu sebesar $64,42 \%$. Ini berarti masih adanya gap antara kompetensi yang dipersyaratkan oleh perusahaan dan kompetensi yang dimiliki oleh para karyawan.

Salah satu cara dalam mengisi gap kompetensi karyawan adalah dengan pelatihan. Pelatihan dapat membantu para karyawan dalam mengembangkan berbagai keterampilan tertentu yang memungkinkan untuk berhasil pada pekerjaannya saat ini dan mengembangkan pekerjaannya di masa mendatang (Noe, 2012). Selain kinerja, pelatihan juga memiliki 
pengaruh yang signifikan terhadap peningkatan kualitas sumber daya manusia (Ekaningsih, 2013) dan competitive advantage (Batool, 2012). Analisa kebutuhan pelatihan atau Training Need Analysis (TNA) merupakan langkah strategis untuk mengetahui program pelatihan yang tepat bagi organisasi dan karyawan (Wulandari, 2005). Selain itu, untuk menghasilkan pelatihan yang efektif, para professional pelatihan perlu menekankan doing the right things the first time. TNA merupakan bagian terpadu untuk memperoleh gambaran komprehensif tentang materi, alokasi waktu tiap materi, dan strategi pembelajaran yang sebaiknya diterapkan dalam penyelenggaraan pelatihan. Program-program pelatihan yang dilaksanakan oleh Adaro belum efektif dan belum dapat mendukung tujuan strategis perusahaan karena belum berdasarkan pada analisis terhadap kebutuhan pelatihan dan belum melalui tahapan-tahapan pelatihan yang terencana dan terprogram.

Selanjutnya, dari uraian fakta fenomena di atas, dapat diajukan pertanyaan penelitian (rumusan masalah) sebagai berikut: apakah kompetensi dan pelatihan yang terjadi di PT. Adaro Energy Tbk, baik secara parsial maupun simultan, berpengaruh terhadap kinerja para karyawannya. Adapun secara ringkas, tujuan penelitian ini ialah untuk membuktikan dan menjelaskan seberapa kuat pengaruh kompetensi dan pelatihan terhadap kinerja karyawan di PT Adaro Energy Tbk.

\section{KAJIAN PUSTAKA}

Kinerja merupakan suatu fungsi dari motivasi dan kemampuan. Untuk menyelesaikan tugas atau pekerjaan seseorang sepatutnya memiliki derajat kesediaan dan tingkat kemampuan tertentu. Kinerja merupakan perilaku yang nyata yang ditampilkan setiap orang sebagai prestasi kerja yang dihasilkan oleh karyawan sesuai dengan perannya dalam perusahaan (Rivai, 2010).

Terdapat 6 (enam) dimensi dalam menentukan kinerja seseorang menurut Rivai (2010), yaitu:

1. Kemampuan atas pekerjaan, hal ini berkaitan dengan kemampuan seseorang dalam melaksanakan tugas yang diberikan atau yang menjadi tanggung jawabnya.

2. Kuantitas kecepatan menyelesaikan pekerjaan, yaitu jumlah pekerjaan yang mampu diselesaikan sesuai dengan waktu yang ditetapkan atau sesuai dengan target yang ditetapkan untuk tiap karyawan.

3. Ketelitian/keakuratan, hal ini berkaitan dengan kecermatan, kerapihan, kebenaran dan kecakapan dalam bekerja sehingga hasil kerja secara menyakinkan sesuai dengan tugas yang diberikan.

4. Loyalitas, yaitu berkaitan dengan kesediaan karyawan untuk lebih mengutamakan penyelesaian tugas yang diberikan untuk kepentingan perusahaan yang disertai dengan penggunaan waktu yang baik yang dijadwalkan maupun yang tidak, baik di dalam perusahaan maupun di luar perusahaan untuk kemajuan perusahaan.

5. Inisiatif, yaitu berkaitan dengan kemampuan dan mau meningkatkan serta memutahirkan hasil kerja untuk kepentingan perusahaan yang dapat dibuktikan ada tidaknya inisiatif dari karyawan dalam memperbaiki hasil kerja, baik diminta ataupun tidak oleh perusahaan.

6. Kerjasama, yaitu kemampuan menjalin hubungan baik pada unit kerjanya atau unit kerja lainnya atau dengan pihak lain di luar perusahaan dalam melaksanakan tugas, bersedia memberikan pendapat dan mau menerima pendapat orang lain serta bersedia menerima keputusan yang bertentangan dengan pendapatnya. 
Kompetensi adalah suatu kemampuan untuk melaksanakan atau melakukan suatu pekerjaan atau tugas yang dilandasi atas keterampilan dan pengetahuan serta didukung oleh sikap kerja yang dituntut oleh pekerjaan tersebut (Wibowo, 2010). Dengan demikian kompetensi menunjukan keterampilan atau pengetahuan yang dicirikan oleh profesionalisme dalam suatu bidang tertentu dan diaplikasikan guna meningkatkan manfaat yang disepakati. Kompetensi juga menunjukan karakteristik pengetahuan dan keterampilan yang dimiliki atau dibutuhkan oleh setiap individu yang memampukan mereka melakukan tugas dan tanggung jawab mereka secara efektif dan meningkatkan standar kualitas profesional dalam pekerjaan mereka. Kompetensi menjelaskan apa yang dilakukan orang ditempat kerja pada berbagai tingkatan dan memperinci standar masing-masing tingkatan, mengidentifikasi karakteristik pengetahuan dan keterampilan yang diperlukan oleh individu yang memungkinkan menjalankan tugas dan tanggung jawab secara efektif dalam mencapai standar kualitas profesional dalam bekerja.

Wibowo (2010) menyatakan bahwa kompetensi merupakan landasan dasar karakteristik orang dan mengindikasikan cara berperilaku atau berpikir, menyamakan situasi, dan mendukung untuk periode waktu cukup lama. Terdapat 5 (lima) karakteristik atau komponen kompetensi yaitu :

1. Motif, adalah sesuatu yang secara konsisten dipikirkan atau diinginkan orang yang menyebabkan tindakan motif mendorong, mengarahkan dan memilih prilaku menuju tindakan atau tujuan tertentu.

2. Sifat, adalah karakteristik dan respon yang konsisten terhadap situasi dan informasi.

3. Konsep Diri, adalah sikap, nilai-nilai atau citra diri seseorang, percaya diri merupakan keyakinan orang bahwa mereka dapat efektif, dalah hampir setiap situasi adalah bagian dari konsep diri setiap orang.

4. Pengetahuan, adalah informasi yang dimiliki orang dalam bidang spesifik, pengetahuan merupakan kompetensi yang komplek, skor pada tes pengetahuan sering gagal memprediksi prestasi kerja karena gagal mengukur pengetahuan dan keterampilan dengan cara yang sebenarnya dipergunakan dalam pekerjaan.

5. Keterampilan, adalah kemampuan mengerjakan tugas fisik atau mental tertentu, kompetensi mental atau keterampilan kognitif termasuk berfikir analitis dan konseptual.

Pelatihan adalah upaya yang direncanakan oleh suatu perusahaan untuk mempermudah pembelajaran para karyawan tentang kompetensi-kompetensi yang berkaitan dengan pekerjaan. Kompetensi tersebut meliputi pengetahuan, keterampilan, dan perilaku-perilaku yang sangat penting atau berpengaruh langsung terhadap kinerja karyawan. Sasaran pelatihan bagi karyawan adalah menguasai pengetahuan, keterampilan, dan perilaku yang ditekankan pada programprogram pelatihan serta menerapkannya kedalam aktivitas-aktivitas sehari-hari (Noe, 2012).

1. Penilaian kebutuhan. Penilaian kebutuhan yang mengacu pada proses yang digunakan untuk menentukan apakah pelatihan diperlukan.

2. Kesiapan terhadap pelatihan. Mengevaluasi apakah para karyawan sudah siap untuk belajar.

3. Menciptakan lingkungan pembelajaran. Memastikan peserta pelatihan dapat memperoleh pengetahuan dan berbagai keterampilan pada program pelatihan serta menerapkan informasi tersebut pada pekerjaannya.

4. Memastikan Peralihan Pelatihan. Mengacu pada penggunaan pengetahuan, keterampilan, dan perilaku yang dipelajari pada pelatihan di tempat kerja.

5. Memilih Metode Pelatihan. Terkait dengan pemilihan metode pelatihan untuk mencapai pelatihan yang efektif. 
6. Mengevaluasi Program Pelatihan. Memeriksa hasil suatu program pelatihan dalam mengevaluasi kefektifannya.

\section{Kerangka Pemikiran}

1. Pengaruh Kompetensi terhadap Kinerja. Terdapat hubungan positif antara pendidikan dan pelatihan yang dialami karyawan dengan kompetensi yang dimilikinya (Alainati, 2010). Pada dasarnya, kompetensi SDM adalah motor penggerak dan penentu kinerjanya. Hal ini diperkuat oleh hasil penelitian Ismail dan Abidin (2010) yang telah membuktikan bahwa kompetensi memiliki pengaruh positif signifikan terhadap kinerja. Demikian pula disampaikan oleh Wang (2007), dalam penelitiannya juga menyatakan kompetensi dan kinerja saling mempunyai hubungan yang positif. Hasil temuan penelitian serupa dan memperkuat proposisi tersebut adalah dikemukakan oleh Jansen (2000), Wright (1997).

2. Pengaruh Pelatihan terhadap Kinerja. Pelatihan berfungsi untuk membina dan mengembangkan kemampuan karyawan sehingga dapat mencapai kinerja yang optimal. Satu diantara sekian banyak tujuan program pelatihan yang dilakukan manajemen ialah untuk meningkatkan kompetensi karyawan, yang pada akhirnya akan berdampak pada prestasi kerjanya. Dalam penelitian Sultana et.al (2012) menyebutkan jika organisasi berinvestasi dalam pelatihan, karyawan dapat meningkatkan kinerjanya. Kesimpulan penelitian Shaneen et.al (2013) dan Amin et.al (2013) juga menjelaskan bahwa pelatihan adalah proses yang berkesinambungan untuk meningkatkan kinerja karyawan, dan pelatihan mempunyai pengaruh positif dan korelasi yang sangat kuat terhadap kinerja karyawan (Noe, 2012).

3. Pengaruh Kompetensi dan Pelatihan terhadap Kinerja. Hasil penelitian yang dilakukan oleh Hariani (2015) membuktikan secara bersama-sama bahwa variabel kompetensi dan pelatihan berpengaruh positif dan signifikan terhadap kinerja karyawan. Aspek yang paling besar pengaruhnya adalah kompetensi. Hal senada juga disampaikan dalam penelitian Fikri (2010) yang menemukan bahwa kompetensi dan pelatihan secara bersama-sama mempunyai pengaruh positif dan signifikan terhadap kinerja karyawan. Rekomendasi dari penelitian tersebut agar perusahaan menaruh perhatian terhadap peningkatan kompetensi dan memikirkan program pelatihan yang efektif.

Berdasarkan beberapa referensi penelitian di atas, selanjutnya dapat disusun kerangka model konseptual penelitian sebagai berikut:

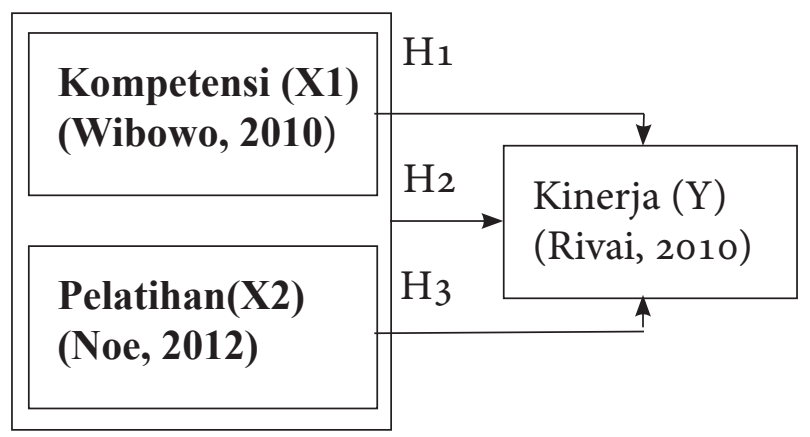

Gambar 1. Model Konseptual Penelitian

\section{Hipotesis}

Sesuai identifikasi masalah, kajian teori dan kerangka pemikiran, maka dapat dirumuskan hipotesis sebagai berikut: 
H1: Kompetensi berpengaruh positif signifikan terhadap kinerja karyawan PT Adaro Energy Tbk.

H2: Pelatihan berpengaruh positif signifikan terhadap kinerja karyawan PT Adaro Energy Tbk.

H3: Kompetensi dan kelatihan secara bersama-sama berpengaruh positif signifikan terhadap kinerja karyawan PT Adaro Energy Tbk.

\section{METODE PENELITIAN}

Penelitian ini bertujuan untuk menguji pengaruh variabel kompetensi dan pelatihan terhadap kinerja, baik secara parsial maupun simultan. Adapun metode penelitian yang digunakan adalah metode survai dengan disain penelitian asosiatif. Penelitian mengambil populasi seluruh karyawan PT Adaro Energy Tbk yang mempunyai masa kerja di perusahaan minimal satu tahun.

\section{Variabel Penelitian dan Operasionalisasinya}

Variabel penelitian dan operasionalisasinya ke dalam dimensi dan indikator dapat dilihat pada Tabel 1. Variabel kompetensi dan pelatihan, masing-masing dijelaskan oleh 5 (lima) variabel dimensi dan data diukur melalui 10 item indikator. Sedangkan untuk variabel kinerja dijelaskan oleh 6 variabel dimensi dan data diukur melalui 12 item indikator. Selanjutnya, dari masing-masing indikator tersebut dibuat instrumen penelitian yaitu berupa kuesioner untuk koleksi data primer.

Tabel 1.

Variabel Penelitian, Dimensi, dan Indikator

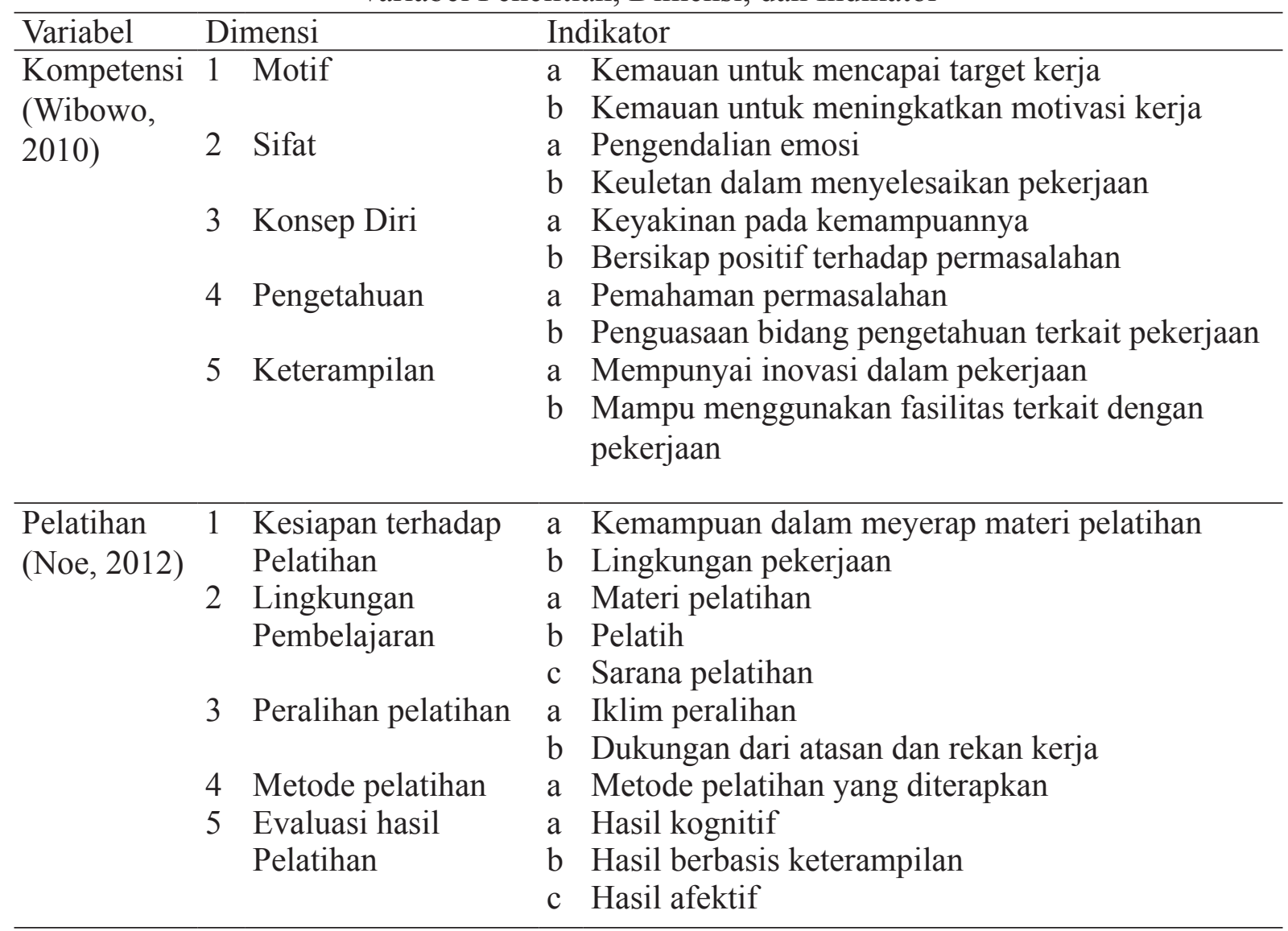




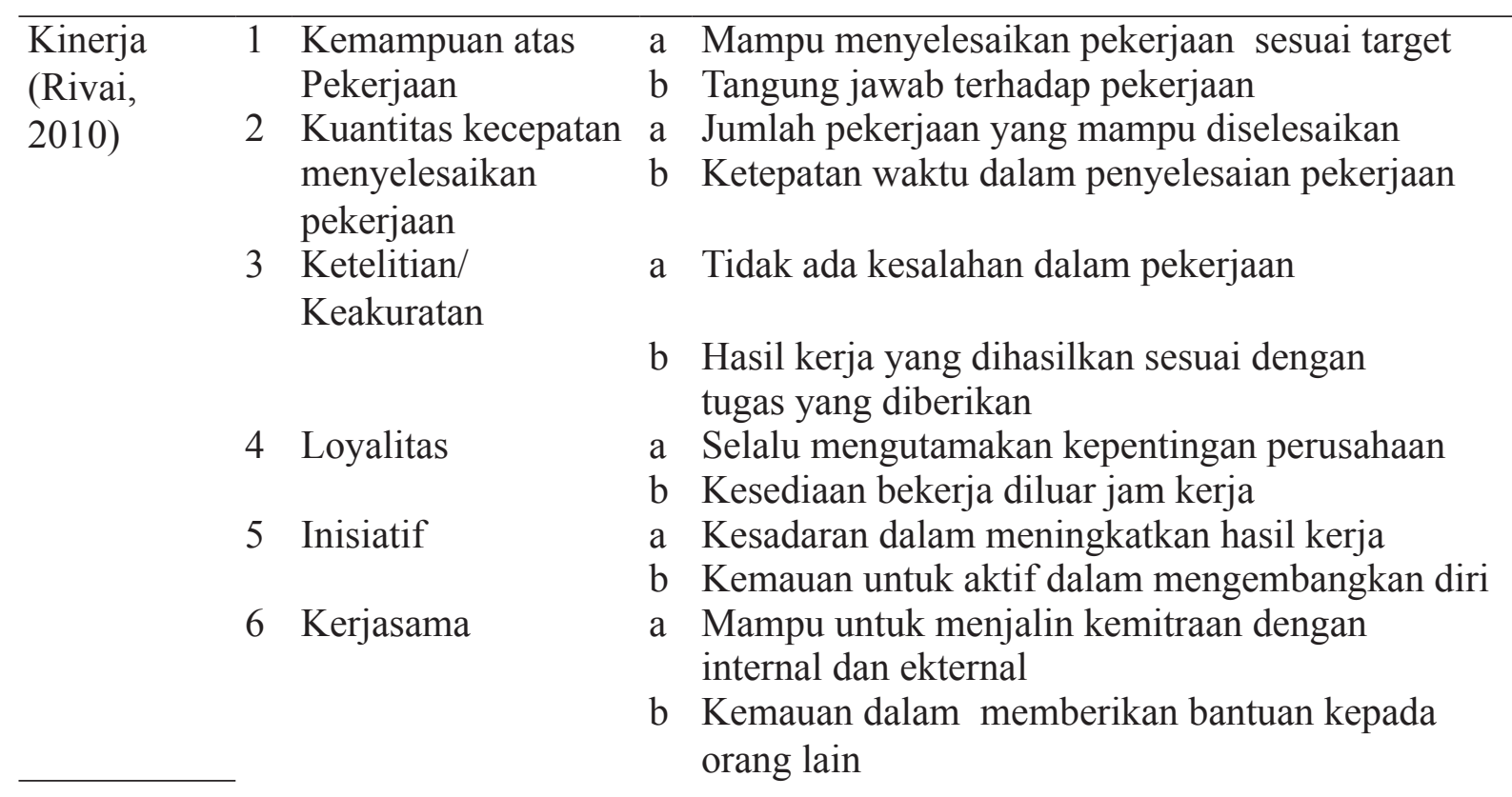

\section{Populasi, Sampel, Sampling, dan Teknik Koleksi Data}

Populasi penelitian ini adalah seluruh karyawan PT Adaro Energy Tbk yang sudah bekerja minimal satu tahun. Dari definisi tersebut maka karyawan yang memenuhi kriteria sebanyak 171 orang. Ukuran sampel minimal ditetapkan berdasarkan rumus Slovin dengan tingkat kesalahan $5 \%$, yaitu sebesar 120 orang. Teknik pengambilan sampel yang digunakan dalam penelitian ini yaitu non probability sampling di mana pemilihan elemen populasi tidak menggunakan proses random. Jenis non probability sampling dipilih adalah sampling insidental, yaitu siapa saja yang secara kebetulan/insidental bertemu dengan penulis dapat ditetapkan sebagai anggota sampel.

Seluruh karyawan PT Adaro Energy Tbk yang ditetapkan sebagai anggota populasi mendapat akses e-mail dan internet. Hal ini memudahkan penulis dalam menyebarkan instrumen kuesioner untuk koleksi data primer melalui akses internet. Penulis memanfaatkan fasilitas google drive. Dengan fasilitas ini maka penulis dapat mendesain dan menyebar kuesioner melalui e-mail kepada seluruh anggota populasi penelitian dengan memberikan link, agar responden dapat mengisi kuesioner secara online. Di samping itu, untuk melengkapi analisis, sejumlah data primer lainnya diperoleh dengan cara observasi di lingkungan kerja karyawan dan wawancara penulis ke beberapa narasumber pimpinan manajemen perusahaan. Sedangkan untuk data sekunder penelitian yang diperlukan dihimpun melalui cara studi pustaka, antara lain jumlah pegawai, hasil penilaian kinerja tahunan karyawan, dan dokumen hasil assessment kompetensi pegawai.

\section{Metode Analisis Data}

Telah disebutkan di atas bahwa penelitian ini menggunakan instrumen kuesioner untuk koleksi data primer. Variabel kompetensi dan pelatihan masing-masing diukur melalui 10 indikator dan tiap-tiap indikator menggunakan minimal kuesioner. Untuk variabel kinerja diukur melalui 12 indikator (Tabel 1). Hasil ukur indikator dirancang melalui opsi jawab berskala Likert pada tiap kuesioner tertutup yang terdiri lima pilihan persepsi ordinal (Tabel 2). Selanjutnya, uji validitas internal kuesioner dilakukan dengan cara uji coba (tryout) pada 
30 respoden. Uji validitas konstruk kuesioner menggunakan teknik korelasi product momment, dan uji konsistensi (reliabilitas) dengan teknik cronbach's alpha.

Tabel 2.

Ketentuan Penilaian Skala Likert

\begin{tabular}{lcc}
\hline \multirow{2}{*}{ Kualitas Persepsi Responden } & \multicolumn{2}{c}{ Skor } \\
\cline { 2 - 3 } & $\begin{array}{c}\text { Pernyataan } \\
\text { Positif }\end{array}$ & $\begin{array}{c}\text { Pernyataan } \\
\text { Negatif }\end{array}$ \\
\hline Sangat Setuju, Selalu, Benar Sekali, Baik Sekali & 5 & 1 \\
Setuju, Sering, Benar, Baik & 4 & 2 \\
Cukup Setuju, Kadang-Kadang, Cukup Benar, Cukup Baik & 3 & 3 \\
Tidak Setuju, Sekali-Kali, Tidak Benar, Tidak Baik & 2 & 4 \\
Sangat Tidak Setuju, Tidak Pernah, Sangat Tidak Baik & 1 & 5 \\
\hline
\end{tabular}

Hasil koleksi data primer pada masing-masing variabel ditujukan untuk menguji rumusan hipotesis penelitian. Metode analisis yang digunakan ialah analisis regresi linier berganda. Dari model regresi tersebut akan diperoleh besaran koefisien regresi $\left(\beta_{\mathrm{i}}\right)$, yaitu untuk menguji hipotesis pertama dan kedua secara parsial. Uji signifikansi parsial koefisien $\beta_{i}$ menggunakan teknik uji $\mathrm{t}$ (t-test). Sedangkan untuk pengujian hipotesis ketiga, yaitu pengaruh simultan dua variabel independen, menggunakan koefisien determinasi $\left(\mathrm{R}^{2}\right)$ dan teknik uji signifikansi $\mathrm{F}$ (F-test).

\section{HASIL DAN PEMBAHASAN}

\section{Hasil Penelitian}

Responden dalam penelitian ini adalah karyawan PT Adaro Energy Tbk yang berukuran sampel sebanyak 133 karyawan. Sebagian besar responden, menurut karakteristik gender, adalah perempuan (55\%), selebihnya laki-laki 45\%. Distribusi responden menurut usia: 20-30 tahun 51,2\%, antara 31-40 tahun 29,3\%, dan di atas 41 tahun 19,5\%. Distribusi menurut masa kerja di PT Adaro Energy Tbk, yaitu kurang dari 3 tahun 33,1\%, antara 3-9 tahun 63,2\%, di atas 9 tahun 3,77\%. Sedangkan menurut golongan (posisi jabatan) ialah General Manajer dan Manajer 18,6\%, Superintendet dan Supervisor 48,1\%, dan Staff biasa 33,8\%.

Hasil uji validitas konstruk instrumen kuesioner, diperoleh koefisien $r$ hitung terendah pada variabel kompetensi 0,526 , variabel pelatihan adalah 0,569 , dan variabel kinerja 0,660 . Nilai terendah koefisien tersebut sudah di atas nilai cut off (batas toleransi terendah koefisien korelasi) yaitu $\mathrm{r}$ tabel $(\mathrm{n}=133 ; \alpha=0,05)=0,17$. Maka dapat disimpulkan semua butir pertanyaan/ pernyataan pada semua variabel penelitian dinyatakan valid. Demikian pula halnya koefisien realibilitas cronbach's alpha, variabel kompetensi 0,885 , pelatihan 0,940 , dan kinerja 0,925 . Semua koefisien reliabilitas tersebut sudah di atas dan memenuhi kriteria koefisien minimal 0,7. Sehingga dapat disimpulkan pula bahwa semua instrumen kuesioner pada masing-masing variabel penelitian adalah reliabel.

Selanjutnya, nilai-nilai koefisien hasil analisis regresi linier berganda pada penelitian ini ialah seperti nampak dalam Tabel 3. 
Tabel 3

Data Hasil Olah (Printout) Model Analisis Regresi Berganda

\begin{tabular}{lrcrc}
\hline Uraian & Koefisien & $\begin{array}{c}\text { Koefisien } \\
\text { Beta Standar }\end{array}$ & $\mathrm{T}_{\text {hitung }}$ & Sig. \\
\hline (Constant) & 1,504 & & 0,606 & 0,546 \\
Kompetensi $\left(\mathrm{X}_{1}\right)$ & 0,952 & 0,726 & 12,064 & 0,000 \\
Pelatihan $\left(\mathrm{X}_{2}\right)$ & 0,158 & 0,183 & 3,044 & 0,003 \\
$\mathrm{~F}_{\text {hitung }}$ & 180,942 & & & \\
$\mathrm{R}^{2}$ & 0,736 & & & \\
Adjusted $\mathrm{R}$ Square & 0,732 & & & \\
\hline
\end{tabular}

Sumber: Data primer diolah, 2015.

Dari Tabel 3, diperoleh persamaan regresi linier berganda sebagai berikut:

$Y=1,504+0,952 X_{1}+0,158 X_{2}$

Koefisien $\beta_{1}=0,952$, adalah positif signifikan $\left(t_{h}=12,064\right.$; sig. $\left.=0,000\right)$. Hipotesis pertama $\left(\mathrm{H}_{1}\right)$ terbukti, yaitu ada pengaruh positif signifikan variabel kompetensi terhadap kinerja karyawan PT Adaro energy Tbk. Derajat kualitas pengaruh kompetensi berada pada level kuat (koefisien $\beta_{1}$ terstandar 0,726).

Koefisien $\beta_{2}=0,158$, adalah positif signifikan $\left(\mathrm{t}_{\mathrm{h}}=3,044\right.$; sig. $\left.=0,003\right)$. Hipotesis kedua $\left(\mathrm{H}_{2}\right)$ terbukti, yaitu ada pengaruh positif signifikan variabel pelatihan terhadap kinerja karyawan PT Adaro Energy Tbk. Derajat kualitas pengaruh berada pada level lemah (koefisien $\beta_{2}$ terstandar 0,183).

Koefisien determinasi (Adjusted $\left.\mathrm{R}^{2}\right)=0,732$, ialah positif signifikan $\left(\mathrm{F}_{\mathrm{h}}=180,942\right.$; sig. $=0,000)$. Hipotesis ketiga $\left(\mathrm{H}_{3}\right)$ terbukti, yaitu ada pengaruh simultan positif signifikan variabel kompetensi dan pelatihan terhadap kinerja karyawan PT Adaro Energy Tbk. Pengaruh simultan dua variabel independen pada model regresi sebesar $73,2 \%$ adalah sangat kuat dan dominan terhadap kinerja karyawan. Atau dengan kata lain bahwa model mampu menjelaskan sebesar 73,2\% keragaman (variasi) perubahan kinerja karyawan PT Adaro Energy Tbk. Sementara itu, besaran 26,8\% keragaman perubahan kinerja karyawan dijelaskan oleh variabel lain di luar model penelitian.

\section{Pembahasan}

Pengaruh Kompetensi terhadap Kinerja. Hipotesis pertama $\left(\mathrm{H}_{1}\right)$ terbukti, yaitu ada pengaruh positif signifikan kuat variabel kompetensi terhadap kinerja karyawan PT Adaro energy Tbk. Kompetensi yang dimiliki semakin tinggi akan membuat kinerja karyawan juga semakin tinggi. Temuan penelitian tersebut sejalan dengan pendapat Wibowo (2010) yang menjelaskan bahwa kompetensi merupakan dimensi perilaku yang berada di belakang kinerja kompeten. Pernyataan tersebut menggambarkan kompetensi sebagai motor penggerak dari suatu kinerja, dan tinggi rendahnya kualitas dari suatu kinerja, dan baik buruknya kinerja dari pelaksanaan kegiatan tertentu. Jansen et.al (2000), Zaim et.al (2013), dan Prasad et.al (2001) dalam penelitiannya juga menyatakan pendapat yang sama bahwa kompetensi mempunyai dampak yang positif terhadap kinerja. Kompetensi karyawan yang meningkat maka kinerjanya juga akan meningkat. Yaitu di antaranya bisa melalui pemberdayaan dimensi-dimensi kompetensi yang dimiliki karyawan, seperti karakteristik motif, sifat, konsep diri, pengetahuan, dan keterampilan, akan mampu meningkatkan kinerja karyawan. Hal ini menunjukkan terjadinya kesesuaian data penelitian lapangan dengan temuan penelitian Emmyah (2009) yang menyatakan bahwa 
karakteristik kompetensi secara simultan sangat berpengaruh positif signifikan terhadap kinerja karyawan. Demikian pula temuan hasil penelitian Suswardji (2012) dan Sundar (2014) yang membuktikan bahwa kompetensi dan kinerja memiliki hubungan yang kuat dan positif. Hal ini juga membuktikan bahwa perusahaan akan terus berkembang dan mampu bertahan apabila didukung oleh karyawan-karyawan yang kompeten di bidangnya.

Dimensi konsep diri pada variabel kompetensi memiliki korelasi paling kuat dengan dimensi kemampuan pada variabel kinerja. Tantangan dan permasalahan yang akan dihadapi perusahaan ke depannya akan semakin tinggi. Perusahaan akan membutuhkan karyawan yang percaya atau yakin akan kemampuannya dan positif melihat tantangan dan masalah yang dihadapi. Bahkan masalah tersebut justru merupakan kesempatan bagi dirinya untuk meningkatkan kemampuannya. Mangkunegara (2006) menjelaskan, upaya pemberdayaan pengetahuan dan keterampilan yang tinggi akan mengakibatkan kemampuan yang tinggi juga. Hal tersebut sejalan dengan penelitian ini, bahwa dimensi pengetahuan dan keterampilan pada variabel kompetensi mempunyai korelasi yang kuat dan signifikan terhadap dimensi kemampuan pada variabel kinerja. Dengan ditambah sikap yang bertanggung jawab dan ulet seperti yang diharapkan manajemen perusahaan kepada karyawan, maka karyawan akan mempunyai kemampuan dalam menyelesaikan tugas dengan baik sesuai dengan target kerja yang diberikan.

Sesuai data hasil observasi peneliti di perusahaan PT Adaro Energy Tbk, secara umum karyawan memiliki karakteristik kompetensi yang baik. Namun demikian perlu diperhatikan bahwa karaktersitik sifat tentang pengendalian emosi karyawan dalam situasi yang tidak kondusif karena isu-isu emosional, hambatan dan blok-blok emosional sering kali dapat membatasi penguasaan kompetensi. Ini kemungkinan terjadi karena beban kerja (work load) karyawan yang tinggi. Cukup banyak karyawan yang sangat sering pulang larut malam karena tuntutan tugas-tugas yang harus diselesaikan secara tepat waktu. Hal ini perlu menjadi perhatian perusahaan karena pengendalian emosi juga terkait dengan kinerja karyawan. Menurut penelitian yang dilakukan Iman (2004) menyebutkan bahwa IQ hanya memberi kontribusi $20 \%$ dari kesuksesan hidup seseorang. Selebihnya bergantung pada kecerdasan emosi dan sosial yang bersangkutan. Di sisi lain, 90\% keberhasilan kerja manusia ternyata ditentukan oleh kecerdasan emosionalnya. Sisanya sekitar 4\% adalah jatah kemampuan teknis.

Pengetahuan tentang pekerjaan akan meningkatkan kinerja karyawan. Agar hal tersebut bisa tercapai, maka karyawan harus lebih mampu memahami berbagai bentuk permasalahan dengan berusaha memahami secara mendalam mengenai faktor-faktor apa saja yang menjadi penyebab permasalahan di perusahaan PT Adaro Energy Tbk. Karena, pada saat ini, yang dirasakan para karyawan terhadap penyelesaian permasalahan yang terjadi hanya ada dipermukaan saja, tapi tidak menyeluruh kedalam. Kewajiban atasan ialah juga perlu menginformasikan dan mendiskusikan masalah yang sedang dihadapi dalam pekerjaannya, sehingga bawahan dapat memahaminya dengan baik.

Keterampilan juga akan membentuk kinerja yang efektif. PT Adaro Energy Tbk, sebagai perusahaan tambang dan energi, improvement atau perbaikan dalam proses kerja sangat penting untuk membangun kinerja perusahan, dan terutama kinerja keuangan. Saat ini yang dirasakan di perusahaan adalah budaya improvement dari karyawan masih perlu ditingkatkan. Jika continuous improvement (perbaikan secara berkelanjutan) dilakukan secara terus menerus, maka kemudian akan menumbuhkan banyak ide atau inovasi sebagai sebuah solusi atas masalah-masalah yang timbul. Hal ini sesuai dengan penelitian yang dilakukan Wright (1997) 
bahwa efektifitas sumber daya manusia akan menjadi kuat jika perusahaan menerapkan strategi inovasi sebagai kompetensi inti karyawan.

Selain budaya improvement, perlu juga ditingkatkan keterampilan karyawan dalam penggunaan fasilitas atau sumber daya lainnya yang diberikan perusahaan sehingga dapat mendukung kinerja karyawan. Masih ada sejumlah fasilitas sumber daya perusahaan yang belum dimaksimalkan penggunaannya. Pelatihan dan penumbuhan kesadaran kepada karyawan akan pentingnya fasilitas sumber daya perusahaan perlu diimplementasikan.

Pengaruh Pelatihan terhadap Kinerja. Hipotesis kedua $\left(\mathrm{H}_{2}\right)$ terbukti, yaitu ada pengaruh positif signifikan lemah variabel pelatihan terhadap kinerja karyawan PT Adaro Energy Tbk. Oleh karena itu program pelatihan harus dilaksanakan dengan baik untuk meningkatkan kinerja karyawan. Hal tersebut sesuai dengan yang disampaikan oleh Khan (2011) serta Al-Zoubi dan Rahman (2011) di dalam penelitiannya menyatakan bahwa pelatihan sangat berpengaruh positif terhadap kinerja. Kesimpulan sementara adalah bahwa proses pelatihan yang dilakukan dengan baik akan mampu meningkatkan kinerja karyawan. Karena itu program pelatihan harus disusun melalui tahapan-tahapan pelatihan yang terencana dan terprogram sehingga memiliki standar mutu yang baik dan mempunyai hasil dan dampak terhadap kinerja karyawan. Hal ini sejalan dengan pendapat Noe (2012) bahwa pelatihan adalah upaya yang direncanakan oleh suatu perusahaan untuk mempermudah pembelajaran para karyawan tentang pengetahuan, keterampilan, dan perilaku yang berkaitan dengan pekerjaan dan sangat penting untuk keberhasilan kinerja perusahaan. Demikian pula yang dinyatakan Gonchkar (2012) dan Shaheen (2013), dalam penelitiannya menguatkan bahwa pelatihan mempunyai pengaruh positif signifikan terhadap peningkatan kinerja karyawan.

Dari hasil analisis korelasi diperoleh koefisien yang membuktikan tingkat keeratan hubungan antara pelatihan dengan kinerja adalah sangat rendah. Tingkat korelasi yang sangat rendah menandakan program pelatihan yang disusun perusahaan PT Adaro Energy Tbk belum melalui tahapan-tahapan pelatihan yang terencana dan terprogram dengan baik. Berdasarkan hasil pengamatan yang dilakukan peneliti, program pelatihan yang disusun perusahaan memang belum dilakukan melalui tahapan-tahapan pelatihan yang terencana dan terprogram, dan sesuai dengan kebutuhan perusahaan. Sehingga hasil pelaksanan program pelatihan selama ini belum maksimal mendukung kinerja karyawan. Menurut Noe (2012) karakteristik utama dari aktivitas pelatihan yang berkontribusi terhadap daya saing adalah apabila aktivitas tersebut dirancang sesuai dengan proses perancangan pengajaran. Proses perancangan pelatihan mengacu pada pendekatan sistematis untuk mengembangan program-program pelatihan. Proses perancangan pengajaran menekankan bahwa praktik-praktik pelatihan yang efektif melibatkan lebih dari hanya memilih penyedia pelatihan dan metode pelatihan yang paling terkenal atau paling bersemangat.

Dalam penelitian ini indikator materi pelatihan, pelatih dan metode pelatihan mendapat tanggapan paling rendah oleh respoden. Karena itu perusahaan perlu melakukan analisis lebih mendalam mengenai materi pelatihan, pelatih dan metode pelatihan yang tepat untuk karyawan sehingga dapat mendukung karyawan dalam mejalankan tugas-tugasnya. Analisis kebutuhan pelatihan yang berguna untuk menentukan pelatihan apa yang diperlukan belum dilakukan PT Adaro Energy Tbk secara maksimal. Hal-hal yang mendukung terciptanya pelatihan yang efektif seperti materi, pelatih dan metode pelatihan belum sesuai dengan kebutuhan secara maksimal juga. Sehingga hasil dari pelatihan yang telah dilaksanakan selama ini belum banyak berdampak strategis terhadap tujuan perusahaan. 
Pengaruh Kompetensi dan Pelatihan terhadap Kinerja. Hasil pengujian hipotesis ketiga juga terbukti bahwa kompetensi dan pelatihan berpengaruh positif dan signifikan terhadap kinerja karyawan PT Adaro Energy Tbk. Pengaruh simultan sebesar 73,6\%, adalah menunjukkan sangat dominan variabel kompetensi dan pelatihan sebagai penentu naik turunnya kinerja karyawan perusahaan. Hasil ini sejalan dengan penelitian yang dilakukan oleh Cahyadi (2012) dan Kunartinah (2010). Sangat dominannya kedua variabel tersebut sebagai penentu kinerja karyawan PT Adaro Energy Tbk, membuktikan bahwa perubahan meningkat kinerja karyawan sangat tergantung kepada kompetensi yang dimiliki dan juga pada program pelatihan yang dilaksanakan oleh perusahaan.

Peningkatan kinerjakaryawanjuga akan berdampak kepada peningkatankinerja perusahaan secara keseluruhan karena karyawan merupakan penggerak seluruh kegiatan perusahaan dalam rangka mencapai target yang telah ditetapkan. Oleh sebab itu, upaya manajemen perusahaan dalam membangun kinerja organisasi, sangat penting manajemen mengambil tindakan-tindakan strategis untuk meningkatkan kompetensi karyawan dan menyusun program-program pelatihan yang terencana dan selaras dengan tujuan perusahaan.

Perusahaan perlu mengatasi hambatan-hambatan dalam rangka peningkatan kompetensi. Contoh hambatan tersebut menurut Zwell (2000) adalah Admitting Incompetency. Atasan dan karyawan secara dewasa harus memetakan kekurangan kompetesi karyawan sehingga dapat dilakukan usaha untuk memperbaikinya. Setelah itu atasan perlu menyusun Individual Development Plan (IDP) secara cermat agar dapat mendukung peningkatan kompetensinya. Implementasi IDP harus didukung penuh oleh atasan dan dimonitor secara periodik untuk memastikan seluruh IDP dilaksanakan oleh karyawan secara benar dan tepat waktu sehingga hambatan-hambatan lain dalam peningkatan kompetensi bisa dihindarkan.

Tujuan dari pelatihan adalah memperbaiki kinerja. Namun pelatihan yang terencana dan terprogram yang sesuai dengan tujuan perusahaan (Noe, 2012). Sehingga manfaat pelatihan, yaitu meningkatkan kuantitas dan kualitas produktivitas dapat dirasakan. Penilaian kebutuhan pelatihan yang terdiri dari analisis organiasi, analisis individu, dan analisis tugas, merupakan langkah awal strategis dalam menyusun program pelatihan efektif. Dengan pemetaan dan penilaian kebutuhan yang cermat akan membantu tersedianya informasi kelayakan pelatihan, dapat membantu mengidentifikasi individu yang membutuhkan pelatihan, serta tugas-tugas, pengetahuan, keterampilan, serta berbagai perilaku penting yang perlu ditekankan pada pelatihan. Dengan informasi ini maka akan didapat gambaran lengkap tentang materi, alokasi waktu tiap materi, dan strategi pembelajaran yang tepat agar pelatihan bermanfaat bagi peserta pelatihan dan mendukung kinerja perusahaan.

\section{SIMPULAN DAN SARAN}

Berdasarkan hasil penelitian dan pembahasan tentang pengaruh kompetesi dan pelatihan terhadap kinerja karyawan PT Adaro Energy Tbk, maka diperoleh kesimpulan sebagai berikut:

1. Hasil pembuktian hipotesis pertama adalah kompetensi memiliki pengaruh yang positif signifikan terhadap kinerja. Tingkat keeratan hubungan antara kompetensi dengan kinerja adalah kuat. Dari hasil penelitian ini diperoleh informasi bahwa kompetensi yang tinggi dimiliki karyawan, yaitu terdiri dari dimensi karakteristik motif, sifat, konsep diri, pengetahuan, dan keterampilan, akan mampu meningkatkan kinerja karyawan. 
2. Hasil pembuktian hipotesis kedua menunjukkan pelatihan memiliki pengaruh yang positif dan signifikan terhadap kinerja. Tingkat keeratan hubungan antara pelatihan dengan kinerja adalah sangat rendah. Dari hasil penelitian ini didapat manfaat bahwa proses pelatihan yang dilakukan dengan baik dan berpijak pada TNA yang cermat akan mampu meningkatkan kinerja karyawan. Namun tingkat korelasi yang sangat rendah menandakan bahwa pelatihan yang telah dilaksanakan selama ini oleh perusahaan belum berdasarkan proses yang terencana dan terprogram.

3. Hasil pembuktian hipotesis ketiga ialah menunjukkan kompetensi dan pelatihan secara bersama-sama (simultan) mempunyai pengaruh positif signifikan terhadap kinerja. Koefisien determinasi sebesar 73,6\%. Hal ini mempertegas bahwa upaya peningkatan kinerja karyawan dalam melaksanakan pekerjaannya sangat tergantung pada seberapa baik kompetensi yang dimiliki karyawan dan seberapa efektif pelatihan yang diselenggarakan perusahaan.

Dengan mengacu pada kesimpulan hasil penelitian maka dapat disampaikan beberapa saran kepada pihak-pihak yang terkait dengan penelitian ini.

1. Dari aspek karakteristik kompetensi yang dimiliki karyawan sudah baik. Namun perlu ada peningkatan dalam hal:

a) Karakteristik konsep diri. Dimensi kompetensi ini mempunyai korelasi yang kuat dengan dimensi kemampuan pada variabel kinerja. Oleh karena itu maka karyawan harus meningkatkan ekspektasi positif baik mengenai dirinya, orang lain dan masalah yang akan dihadapi. Dibutuhkan pelatihan problem solving and decision making untuk mempermudah karyawan dalam mengidentifikasi dan memformulasikan masalah yang dihadapi, dan menetapkan solusi terbaik.

b) Karakteristik sifat yang terkait dengan kemampuan karyawan dalam mengendalikan emosi. Jika karena beban kerja yang cukup tinggi perusahaan perlu melakukan analisis beban kerja untuk memastikan jumlah karyawan telah mencukupi..

c) Terkait dengan Karakteristik pengetahuan, agar karyawan perlu mengetahui permasalahan yang dihadapi, para atasan sangat perlu melibatkan bawahan dalam penyusunan rencana kerja tahunan Departemen atau Divisi, sehingga permasalahan yang akan dihadapi di depan dapat diketahui oleh karyawan.

d) Untuk karakteristik keterampilan, sangat perlu disusun program-program yang berkaitan dengan continuous improvement agar continuous improvement bisa membudaya di perusahaan. Guna menghadapi hambatan dalam menggunakan fasilitas dan sumber daya yang diberikan perusahaan, atasan bisa melakukan coaching kepada karyawan tersebut atau diikutkan dalam pelatihan yang sesuai dengan kebutuhan.

2. Perusahaan perlu segera menyusun analisis kebutuhan pelatihan (TNA) agar kegiatan pelatihan bisa terarah dan efektif. TNA meliputi analisis organisasi, analisis individu, dan analisis tugas. Disarankan agar seluruh karyawan harus mempunyai individual development planning (IDP) yang berisi rencana pengembangan karyawan sesuai dengan kebutuhan perusahaan untuk jangka waktu tertentu. Atasan diwajibkan untuk menyusun IDP para bawahannya. IDP tersebut bisa menjadi bahan analisis yang salah satunya adalah dalam menyusun program pelatihan.

3. Diperlukan penelitian lanjutan tentang faktor-faktor lain yang mempunyai pengaruh terhadap kinerja karyawan PT Adaro Energy Tbk di luar variabel kompetensi dan pelatihan. Variabel-vaiabel penelitian atau faktor-faktor lain dimaksud di antaranya ialah kecerdasan 
emosional, komitmen, gaya kepemimpinan, system karir, kompensasi, dan lain sebagainya. Dengan mengetahui besaran pengaruh variabel-variabel SDM tersebut terhadap kinerja karyawan, maka perusahaan dapat lebih fokus dalam melakukan perbaikan-perbaikan untuk membangun kinerja karyawan.

\section{REFERENSI}

Amin, Anam, et.al. 2013. The Impact of Employees Training On the Job Performance in Education Sector of Pakistan. Middle-East Journal of Scientific Research, Vol.17 (9).

Al-Zoubi, Suhail Mahmoud dan Majdoleen Sultan Bani Abdel Rahman. 2011. The Effects of a Training Program in Improving Instructional Competencies for Special Education Teachers in Jordan. International Research Journals. Vol.2 (3).

Batool, Abeeha. 2012. Effects of employees training on the organizational competitive advantage: Empirical study of Private Sector of Islamabad, Pakistan. Far East Journal of Psychology and Business, Vol.6 (1).

Cahyadi, Arief. 2012. Pengaruh Kompetensi, Pelatihan, Motivasi terhadap Kinerja Pegawai Pengelola Kepegawaian Kementrian Kesehatan. Tesis Pascasarjana. Jakarta: Universitas Mercu Buana.

Ekaningsih, Ana Sari. 2013. Peran Pendidikan dan Pelatihan serta Kompetensi Dalam Upaya Peningkatan Kualitas Sumber Daya Aparatur. Jurnal Borneo Administrator. Vol.9 (2).

Emmyah. 2009. Pengaruh Kompetensi Terhadap Kinerja Pegawai pada Politeknik Negeri Ujung Pandang. Tesis Pascasarjana. Makasar: STIA LAN.

Fikri, Zaini. 2010. Pengaruh Kompetensi dan Pelatihan terhadap Kinerja Pegawai PSI. Tesis Pascasarjana. Jakarta: Universitas Mercu Buana.

Gonchkar, K. Pramod. 2012. The Impact of Training and Development on Performance of Officers of Select Public Sector Banks for Sustainable Human Development: A Study. OIDA International Journal of Sustainable Development, Vol.5 (7).

Hariani, Wenny. 2015. Pengaruh Kompetensi, Pelatihan, dan Motivasi terhadap Kinerja Karyawan PT Pertamina (Persero) Refinery Unit II Dumai. Jurnal Ekonomika, Vol.1 (1).

Iman, E. 2004. Paradigma Baru Kecerdasan Emosional. http://download.portalgaruda.org/ diakses tanggal 04 April 2015.

Ismail, Rahmah dan Syahida Zainal Abidin. 2010. Impact of Worker's Competence on Their Performance in the Malaysian Private Service Sector. Business And Economic Horizon, Vol.2 (2).

Jansen, Groll RP, Van Der Vleuten Scherpbier AJ, Crebolder HF, Rethans JJ. 2000. Effect of a Short Skills Training Course on Competence and Performance in General Practice. Jurnal Pendidikan Kesehatan, Vol. 34 (1).

Kunartinah. 2010. Pengaruh Pendidikan dan Pelatihan, Pembelajaran Organisasi terhadap Kinerja dengan Kompetensi sebagai Mediasi. Jurnal Bisnis dan Ekonomi, Vol.17 (1). 
Khan, Raja Abdul Ghafoor. 2011. Impact of Training and Development on Organizational Performance. Global Journal of Management and Business Research, Vol. 11 (7) Version 1.0.

Mangkunegara, AP. 2006. Evaluasi Kinerja Sumber Daya Manusia. Bandung: Refika Aditama.

Noe, Raymond A. , John R. Hollenbeck, Barry Gerhart., Patrick M. Wright. 2012. Manajemen Sumber Daya Manusia untuk Keunggulan Bersaing Organisasi. Jakarta: Salemba Empat.

Prasad, Kanti., K. Ramamurthy., dan G.M. Naidu. 2001. The Influence of InternetMarketing Integration on Marketing Competencies and Export Performance. Journal of International Marketing, Vol.9 (4).

Rivai, Veithzal. 2010. Manajemen Sumber Daya Manusia untuk Perusahaan. Edisi Ketiga. Jakarta: Raja Grafindo Persada.

Shaheen, Azara. 2013. Employees Training and Organizational Performance: Mediation by Employees Performance. Interdisciplinary Journal of Contemporary Research and Business, Vol.5 (4).

Sultana, Afsan., Sobia Irum., Kamran Ahmed., Nasir Mehmood. 2012. Impact of Training on Employee Performance: Study of Telecomunication Sector in Pakistan. Interdisciplinary Journal of Contemporary Research and Business. Vol.4 (6).

Sundar, Shalini. 2014. A Study on the Influence of Leadership Styles and Competency on Performance in the Manufacturing Industry. Jurnal Internasional Penelitian Ilmiah, Vol.3 (9).

Suswardji, Edi. 2012. Hubungan Kompetensi dan Disiplin Kerja terhadap Kinerja Kependidikan Universitas Singaperbangsa Karawang. Jurnal Manajemen. Vol.10 (1).

Wang, Hsi-Kong Chin. 2007. A Study on the Relationships among Knowledge Management, Situational Factors, Professionals' Core Competencies and Job Performance-Taking the Vocational Training Centers and Employment Service Centers as Example. The Journal of Human Resource and Adult Learning. Vol. 3 (2).

Wibowo. 2010. Manajemen Kinerja. Jakarta: PT. Raja Grafindo Persada.

Wulandari, Retno. 2005. Penilaian Kebutuhan Pelatihan: Tantangan dan Solusi. Jurnal Siasat Bisnis. Vol.5 (1).

Wright, Patrick M. 1997. Strategy, Core Competence and HR Involvement as Determinants of HR Effectiveness and Refinery Performance. Human Resource Management Journal. Vol.37 (1).

Zaim, Halil., Mehmet Fatih Yaşar., Ömer Faruk Ünal. 2013. Analyzing The Effect of Individual Competencies of Performance : A Field Study in Services Industries in Turkey. Journal of Global Strategic Management, Vol. 14 (2).

Zwell, Michael. 2000. Creating a Culture of Competence. New York: John Wiley \& Sons, Inc. 
